\title{
RIDDLES AND HUMOUR
}

\author{
Annikki Kaivola-Bregenhøj \\ University of Turku, Finland \\ e-mail: annikki.bregenhoj@elisanet.fi
}

\begin{abstract}
Why do riddles amuse their users and listeners? A riddle exists in a performance context in which all the participants want to enjoy the game. The situation simultaneously involves both entertainment and humiliation, because riddles are intended to mislead the listener: "right" answers are often "wrong". In the Finnish folk tradition, the unsuccessful riddlee could be sent to Hymylä, which was a fictitious topsy-turvy world. It was frightening and humiliating for the riddlee to be sent there. Riddling demands that the riddlee learns to tolerate being laughed at.
\end{abstract}

Keywords: humour, Hymylä, joking question, laughter, performance, riddle, riddling, sexual riddle, situation, true riddle

In this article I examine riddles, old and new, and riddling material in the Folklore Archives of the Finnish Literature Society. In 1967 the archives wanted to expand their riddle collections and, accordingly, asked people to submit both riddles and information about riddling situations at which they had been present. This was the first enquiry dealing solely with riddles, and it was published in the Folklore Archives' periodical Kansantieto (Folk Knowledge). Some 30,000 riddle variants were submitted, along with 68 reports of contexts. Some of these were only brief, but there were also some detailed descriptions of social occasions on which riddles had been posed. The descriptions had one thing in common: the riddling had been fun and it had produced plenty of laughs. "Everyone had fun" or someone was "quick-witted and always game for some humour and little digs" (SKS KRA: Elsa Jaatinen Jyväskylä AK 6:139.1967). The enquiry was made just in time, because it was then still possible to find people with personal memories of riddling, a genre fast vanishing in the changing society. It jogged their memories by giving the opening words of riddles, which readers then completed and sent to the Folklore Archives. Writers did not, however, specify what made them laugh, but then again, they were not asked to do so.

In an attempt to find out why riddles amused people, I analyse them from different eras. I concentrate on verbal tradition and in this article omit, for 
example, droodles and other non-oral riddles in which a humorous situation "is not created, described and expressed by a text" (Raskin 1985: 46). Droodles, for example, which have been widely researched (Price 1953; Klintberg 1978; Preston 1982; Roemer 1982; Voolaid 2009), require an ability to read the image, but the riddlee may need to stop and consider for a moment the right answer to the expression represented by the image. By contrast, oral riddles require a rapid ability to interpret the image correctly. Why does word play in riddles make people laugh? Are riddles entertaining because success alternates with failure? Is the laughter the result of nervous tension: what if my "correct" answer does not satisfy the riddler? Who holds the upper hand? When reading dozens and even hundreds of riddle variants, the researcher begins to have some idea of the fun and humour inherent in riddles.

A riddle detached from its context does not necessarily make the researcher laugh. It acquires a life of its own in performance. When I read so-called "true riddles" and present-day so-called "joking questions", I search for hints and keys to the comic element and humour of riddles in the context information found in the descriptions. I reflect on the riddler's attitude, and the power he or she wields when posing the question. If humour is a combination of violating a norm, surprise, and hyperbole (Bregenhøj 1988: 181), then how are these characteristics manifested in riddles? When something amuses us, we enjoy what "clashes with our mental patterns and expectations" (Morreall 1989: 1).

Riddles are expressions comprising a question image and an answer. For example: (\#1) "It lives from the beginning of the world to the end of the world but is never five weeks old. Answer: The moon". The image here claims something that, viewed rationally, is impossible. The answer is hidden in the question, which simultaneously both misleads and provides a hint to the right answer. A person skilled in the riddling tradition has in his or her competence a vocabulary characteristic of the genre, a stock of metaphors, and the ability to construct contrasting, antithetical, and paradoxical images. They are also familiar with typical structures, and above all the art of combining these elements of the language of riddles according to the semantic codes peculiar to the genre (Kaivola-Bregenhøj 2001: 130).

Asking riddles - riddling - was mostly a winter leisure pursuit, when people of the house got together to do the handwork and repairs necessary in a selfsufficient household. At the same time, they could tell stories, sing songs, or ask riddles. These situations were important for the transmission of oral tradition in general, for monotonous work was made easier by entertainment in the form of oral folklore. Summer in the farming community was, on the contrary, a very busy time with plenty of work in the fields and less time to have fun. 
Riddling is an exchange of words in which people are deliberately misled because the "right" answer is sometimes completely unexpected. Riddling is not, however, a general knowledge quiz, because the "correct" answer may be "wrong", in other words, arbitrary. Riddling is a social occasion that values entertainment, quick-wittedness, getting the answer right, humiliation and its tolerance. As Akíntúnde Akínyẹmí points out, while speaking of riddles, "the performer and audience often derive equal pleasure and entertainment from participating" (Akínyẹmí 2015: 84). The audience is never passive. For the riddler and the audience the game would be boring if all riddles were easy to guess.

\section{TWO TYPES OF RIDDLES: TRUE RIDDLES AND JOKING QUESTIONS}

In this article I deal with only two types of riddles. One is the true riddle, in which the question contains not only a misleading element but also a hint at the answer, as in the riddle about the moon (\#1). The person who answers the riddlee - is familiar with the genre and knows that the image would not immediately reveal the answer. He or she either has to spot the link between what is misleading and what is true, or he or she already knows the answer. Spotting the semantic fit between the riddle image and the answer is a pleasurable experience.

True riddle images use many different formulas. Some of the formulas and metaphors are international, but each language and cultural area also has models of expression of its own. In Finland the language of riddles bears traces of the metre of archaic Finnish epic poetry. Alliteration is more frequent, whereas rhymes are less common. Only a few true riddles have been preserved. An example with one of the popular formulas is: (\#2) "Mindless, tongueless, tells the truth to all. Answer: A steelyard".

True riddles and joking questions are products of such different eras that they are not often posed on the same occasion. True, the children I met in a Helsinki school in 1973 knew both traditional riddles, such as (\#3) "A black man with a stub nose. Answer: A pot", and new joking questions such as (\#4) "It's blue and eats hay in a field. Answer: A cow wearing a tracksuit" (Kaivola-Bregenh øj 1974: 107-108). Joking questions are contemporary riddles that have nothing in common with the old riddles apart from a question and an unexpected answer.

Riddles abound in seemingly impossible things (Virtanen 1960: 160) that people either have to guess or know beforehand. Ambiguity and incongruity that would be avoided in normal speech are totally acceptable in riddles. As has been 
pointed out, everyone likes the unusual linking of subtle images (Barley 1974: 149). Giving the right answer has been regarded as indicating that the riddler realises that the language is ambiguous. He or she has learnt the cultural art of how to manipulate ambiguity (Haring 1985: 166).

Riddles both hide and reveal their object. They lead the listener astray and seek to provide a new perspective on something familiar to all (Pepicello 1989: 210). A good example of morphological ambiguity is a trick question: (\#5) "What's black and white and red all over? Answer: A newspaper", in which there is a play of homophony between a simple lexical item (the adjective red) and a verb plus its past participle morpheme (read). The possibility of being led astray is always present, and it both perplexes and amuses. The fact that the riddlee grasps the connection between the question and the answer and comes up with the correct answer may also be part of the fun. Riddling teaches people to take the right attitude to the comic element, and there is humour to be found in a form of interaction in which one party holds the upper hand.

Riddling is a promise of fun. It serves as a frame in which all have to be alert and to accept what is coming with a sense of humour. The rules are familiar to all, and people welcome a chance to have fun with others and make the everyday chores easier. Riddling means permission to have some funny exchange of words, even though excessive laughter might otherwise be frowned upon. When Victor Raskin (1985: 47) says, that "[i]deally, a linguistic theory of humour should determine and formulate the necessary and sufficient linguistic conditions for the text to be funny", riddles are an exception. The context - riddling - makes the text funny even though, out of context, it would not be.

\section{SEXUAL RIDDLES}

Sexual riddles may serve as an example of the strange humour of riddles. Sexual riddles are among the most outspoken expressions of folk eroticism. The use of sexual vocabulary is, however, rare in riddles, unlike in other forms of erotic folklore. Riddling in the home is often a family occasion, and in that case the language has to be fit for children's ears.

We do have some information on the contexts in which traditional sexual riddles were used. Among groups of young people this lore has always clearly served the function of raising the erotic temperature. In the farming community there were some jobs done by the young people of the village together, and these situations provided a setting for the transmission of oral tradition. The verbal pranks of a Finnish working community are described as follows: 
In the autumn the malt was sweetened in a malt sauna and spirits were brewed. Usually the work was done by the young girls from the farm. It was a laborious job, because it had to be watched over day and night. The time nevertheless passed quickly, because as soon as the boys caught a whiff of the malt, they sought out the girls and helped them pass the time by dreaming up all sorts of pranks. One popular entertainment was posing riddles for the girls to answer. And the boys were indeed sharp, for many riddles led one's thoughts to something that would make a girl blush and giggle, whereas the object to be guessed might well have been something as innocent as a tobacco pipe or a spoon, or such legitimate pursuits as weaving, spinning or father eating lingonberry porridge out of a bowl in mother's lap. Other riddles were less 'risky'. (Wessman 1949: VII)

Sexual riddles were particularly popular with men. Some of the reports describe riddling among groups of men working in the forests. "We spent the nights in the village sauna out in the forest. There the men would sometimes feel inspired to pose riddles, and then the riddles were ones to do with sexual things" (SKS KRA: Eino A. Hyytinen AK 4:292.1967).

On such occasions it was possible to be amused and laugh openly at the sexual humour, which was sometimes most explicit.

Some folklore collectors mention that women were in the habit of interrupting a game or changing the topic of conversation as soon as anyone began asking sexual riddles. Women's chastity is also underlined: "The farm hands and day labourers were bolder at asking obscener ones, whereas the mothers and serving girls were more respectable" (SKS KRA: Olga Hirvonen AK 3:369.1967).

This information on the use of riddles dates from the extensive collection of Finnish riddles compiled in 1967, and throws light on the situation in the early decades of the twentieth century. But are the details of women's attitudes necessarily as straightforward as this? What was the limit to the presentation of sexual lore? I could ask if women hid the fact that the humour amused them. I am sure they did, because some folklore collectors found that women were as bold as men in posing suggestive riddles. The following quotation, though brief, from an answer given to a Finnish riddle collector, is typical: "The riddles are from the Rajala shoe factory at Kankaanpää, where a [female] worker called Aili Kivelä put them to the young men working alongside her" (SKS KRA: Olavi Määttä AK 12:64.1967). The teasing between men and women is enhanced here by the fact that the riddler is older than her colleagues. But even young girls might ask sexual riddles, giggling and blushing or "turning their faces away as they hand a paper bearing a suggestive text" (Wessman 1949: VII). 
It has quite rightly been pointed out that bashful publishers are responsible for creating the highly proper, yet misleading, picture of folklore as something that is almost antiseptically devoid of sensuality (Launonen 1966: 374). One rare exception is Finnish clergyman Christfrid Ganander, who published the first collection of Finnish riddles, titled Aenigmata Fennica, as early as 1783. Ganander appreciated the value of living tradition and did not censor his publication. The sexual riddle is a living tradition, and one still in use: sexual riddles and jokes are not merely a past form of entertainment, since they are continuously favoured by both adults and children. Mixed groups of adults have from time immemorial cultivated open and risqué sexual humour, so why not sexual riddles too, which, being ambiguous, are exciting. We do, however, have very few descriptions and facts about what people talked about when they got together, and about the type of language permissible on a given occasion.

The riddles in today's Finnish children's tradition may be outspoken, and their humour is often founded on verbal word play. In the African Yorùbá community, sex and sexual organs are not directly mentioned, but they may be indicated euphemistically, and "riddles underscore the importance of sex and sexual organs and allow us to accept their inevitable presence" (Akínyẹmí 2015: 86). When delicate matters are dressed in humour, youngsters learn to speak of them in a way that is socially acceptable. The following examples (here just in English) are deemed suitable for children and young adults: (\#7) "The Olóféèrè bird on the road to Ìbàdàn. That laid two eggs, and placed its chin on them. Answer: Male genital organs - the penis and testicles", and (\#8) "Two bẹnbẹ drums, resting against a baobao tree. Answer: A woman's breasts" (ibid.: 86-87).

Erotic teasing and laughter are typical of the riddle tradition, but is this really humour? There could be several answers, because expressions interpreted as humour are culture-specific and always tied to the performance.

Erotic joking or the generation of an erotic charge is easy with the help of short joking questions. I quote two American sexual jokes analysed by Pertti J. Anttonen (2000): (\#9) "What's the difference between a beer and a woman? Answer: Beer is wet all the time"; and (\#10) "What's the difference between a Coke and a Man? Answer: Coke comes in a can, but a man comes in your mouth".

Anttonen (2000: 246-256) demonstrates by a close analysis of jokes and their performance contexts that these two sexual jokes were, in an interactive situation observed by him, the last straw that caused the disintegration of a relationship. The words "beer", "wet", "Coke", and "your mouth" became fully charged with totally unforeseen meanings to which the man and the woman gave different interpretations in keeping with their own frame of mind. In telling the jokes, the man intended to be amusing, to provide some light relief, and 
to demonstrate that he wanted the relationship to continue. By contrast, the woman found the key words offensive, and the man's feeble attempt at trying to make her laugh made her all the more determined to put an end to the affair.

The true meaning of joking is only revealed in context, which demonstrates how differently people may interpret the same sexual riddles. One may be offended by something that another regards as liberating humour.

\section{A CHANGING TRADITION}

The riddle tradition began to change in the 1960s. The imagery of the old riddles in Finland was drawn from the agrarian domain, and a uniform culture. Both the questions and the answers therefore concentrated on life on the farm, women's and men's jobs, domestic animals, and just occasionally the forest and vicinity beyond the farmyard. The agrarian way of life became alien with the development of industrialisation, urbanisation, and changes in working life.

Spinning, churning, seine fishing and ploughing became strange work; while things like a still, pothooks, a baker's peel, a spit, carding combs, a sieve, a quern, a quill pen, the runners of a sleigh, a knapsack, a scythe, and millstones became strange articles. Central heating and electric lighting took the place of the fire burning in the oven or the forked stick for holding fir torches, not to speak of innumerable other changes: it was no longer taken for granted that there were lice in people's hair, porridge was eaten from the same bowl, a pig no longer entered the living room, everyone learned to write. (Virtanen 1977: 77-78)

As country folk moved into towns in search of work, old riddles lost their natural context and people no longer understood them. The imagery ceased to amuse them. The complex language of true riddles was also removed from everyday speech.

"The riddle joke is one of the most common joking forms today," says Dorothy Noyes (1997: 731). These riddles are, in fact, a fast-renewing tradition among children and adults alike. The entertainment of riddle jokes may involve attitudes towards important and serious aspects of life, such as religion, politics, work or sex (Brunvand 1970: 128). Elephant jokes have been among the most popular jokes both in the USA and Finland. In the spring of 1964, my fellow student Ulla Lipponen noted down elephant jokes in the student café at Helsinki University, where we used to sit. These riddles described the colour of an elephant, the clothes it was wearing or its adventures in an urban milieu. For example: (\#11) "Why is the elephant wrinkly? Answer: Because no one strokes 
it". Although elephants later went out of fashion in the tradition of young adults, they were still a living part of children's lore in the mid-1980s. In Estonia this type of joking question is still the most popular one (Voolaid 2009: 144).

Another popular joking question is the dumb-blonde jokes, the sexist tone of which does not leave the reader of the joke columns cold. In the autumn of 1993, a boy in my daughter's class entertained 14-year-old girls during the domestic science class with dumb blonde jokes like these: (\#12) "Why did God create blondes? Answer: Because apes never learnt to fetch beer from the fridge"; (\#13) "Why did God create brunettes? Answer: Because the blondes didn't learn to fetch beer from the fridge either"; and (\#14) "How do you reduce a blonde's brains to the size of a pea? Answer: By blowing them up".

A certain theme may be wildly popular while this type of question is in fashion, but it is soon exhausted and the riddles no longer appeal. This rule does not, however, apply to dumb blonde jokes, the reason for whose popularity and viability can only be guessed. There are long strings of dumb blonde jokes circulating on the Internet (Kaivola-Bregenhøj 2001: 58-59). In 1997 Ulla Lipponen was given 50 pages containing some 2,000 joking questions on this theme, which a friend had printed from the Internet, at least some of them variations on the old models (discussion with Ulla Lipponen 2000). And whereas the blonde was still mainly just dumb in the schoolgirl tradition of the early 1990s, today there are also numerous jokes on the Internet telling of her promiscuity, such as (\#15) "Why did the blonde like the car with a sunroof? Answer: More leg-room" (see www.jokebuddha.com), or (\#16) "What's the difference between a blonde and a Porsche? Answer: You don't lend the Porsche out to your friend" (www. jokebuddha.com.Porsche). In any case, the dumb blonde is always a woman and there seems to be no limit to her stupidity. Blonde jokes are very popular also in Estonia, where some are viewed even from a female perspective, for example: (\#17) "Why are blonde jokes so short? Answer: So that men can understand them" (discussion with Piret Voolaid 25.6.2015).

On the one hand, the imagery of the joking question is international, yet, on the other, strictly local. Since we Finns are not familiar with the demography and stereotypes in the USA, the disparaging jokes of the 1960s about poor, dirty Poles do not address us. Some good examples of ethnic joking questions are: (\#18) "What do you get if you pour hot water on a Polack? Answer: Instant shit"; and (\#19) "Do you know why flies have wings? Answer: To beat the Polacks to the garbage" (Davies 1990: 85). The target for ethnic riddles was, in the USA, most often the Polish immigrants. These jokes were often crude, and either the Poles were depicted as simpletons who did everything wrong, or the point of the jest was aimed at their dirtiness or their lowly position in society. Sometimes dirt and stupidity are linked together in ethnic jokes. Of course, there is no 
proof that the Poles are any less hygienic than their fellow citizens in America. It should, on the other hand, be remembered that jokes are not realistic, and nor are these ethnic jokes (Raskin 1985: 205; Davies 1998: 50; 1990: 89, 308). It has subsequently been argued that the Poles acted as a channel for letting off the aggression that could not be openly aimed at the Afro-Americans (Dundes 1971: 186-203). But Christie Davies (1998: 167) thinks - however - that Alan Dundes suggested this erroneously. Many scholarly dissertations based on tradition in oral circulation show that jokes of blacks are both numerous and popular in the United States. A small number of them concern just published collections of jokes.

The humour of ethnic joking questions relies on the listeners' familiarity with the butt of the joke. Their strange humour remains an enigma unless the listener has sufficient context information. The leavening agent of joking questions is the "stupidity script" placing rational, non-stupid "us" side-by-side with stupid, irrational "them". The main function of these riddles is indeed to make fun of "them" and demonstrate "our" superiority (Voolaid 2011: 31-32). Many jokes that raise a laugh elsewhere in the world fall dead in Finland because the cultural context is alien to us. But we do make jokes at the expense of minorities so long as the object is familiar. The expressive models of riddle jokes are easy to reproduce as compared to the language and metaphors of old riddles. Jokes are easy to update so long as people remember that the answer must always be comic or infuriating.

The joking tradition is not, however, just innocent entertainment; both children and adults use it as a means of addressing various aspects of life, such as major disasters. The first wave of worldwide disaster jokes concerned the 1968 war and famine in Biafra. Some of these international jokes also found their way to Finland, for instance: (\#20) "What's the difference between a Biafran child and a ping-pong ball? Answer: Five grams". In the 1980s, I was told some Biafra jokes by some schoolchildren who had dropped in on one of my lectures. In Sweden, many schoolchildren regarded the jokes as sick, yet the jokes spread all the same. It has, however, been stressed that disaster and racist jokes are not always intended to make people laugh (conversation with Ulla Lipponen 2010). There is nothing new about even gross joking about topics that are painful, politically sensitive or have to do with religion. Alan Dundes and Thomas Hauschild (1983: 249) wrote about Auschwitz jokes jeering at the mass murder of the Jews and said, "Nothing is so sacred, so taboo, or so disgusting that it cannot be the subject of humour. Quite the contrary..." One of the strategies of joking is to topple people uppermost in the social hierarchy, such as priests, academics, experienced politicians or people such as doctors in prestigious professions (Brunvand 1970: 129). 
Humour has also been used as a means of addressing politically sensitive issues that could not have been written about in the media. Piret Voolaid (2010: 63, 73-76) has studied what are known as "abbreviation riddles", which are in most cases acronyms. They are both witty and humorous, and their hidden meaning is often either political or sexual. For example, the FBI (Federal Bureau of Investigation) can get the interpretation "Female Body Inspection". In Estonia the main bulk of "alternative abbreviation interpretations" has been collected by some unsanctioned collectors, who understood the importance of storing the material which under the totalitarian Soviet regime was totally ignored. These abbreviations have a strong political flavour; for example, the abbreviation SSSR (Soyuz Sovetskikh Sotsialisticheskikh Respublik - Union of Soviet Socialist Republics) has several different interpretations, the most famous of which in Estonian is "Siberi sead situvad reas", in English "Siberian swine shitting in rows". The top ten of these abbreviations are connected with the Soviet state names, but there are also many interpretations related to Joseph Stalin, like "Stalin sõitis seaga ratsa", in English "Stalin rode on a pig". Christie Davies (1998: 77) points out that "[t]he people portrayed as stupid in Eastern European jokes tended to be the leaders of the Communist Party", like (\#21) "Why do Czech militiamen go round in groups of three? Answer: One can read, one can write, and the third is keeping an eye on the two intellectuals"; or (\#22) "Why was Grechko made a Marshal of the Soviet Union? Answer: Because he was too stupid to be a General".

The majority of the abbreviation riddle jokes faded away after Estonia regained independence in 1991. It was now possible to criticise politicians and the authorities publicly in the media. Where people are free to discuss and criticise politicians, political jokes are less common in oral tradition (Davies 1998: 174-175). But in Estonia the corruption of politicians might still be criticised by means of abbreviation riddles. In school lore, such interpretations have continued; for example: USA (United States of America) as "Uskumatult suur armastus", in English "Unbelievably big love" (Voolaid 2010: 79-80).

Some joking questions have been attached to politics and politicians in Finland, but they are usually language-specific. Some decades ago the Finns made jokes at the expense of their then prime minister. Because Finnish is not, unlike English, an Indo-European language, the English spoken by the Finns is often clumsy. The prime minister in question had on one of his overseas tours visited a zoo and had seen the word "dangerous" on the cages. Hence it gradually dawned on him, or so the story goes, that the word "dangerous" must mean "animal", but he mispronounced it as "tankero". This sparked off a host of "tankero" jokes, all targeted at the mispronunciation of English. In the 1970s the prime minister is said to have asked room service to bring: "tuu tii to töötituu" (two teas to [room] thirty-two) (see https://en.wikipedia.org/wiki/Tankero). 
The popular riddle formula based on similarities and dissimilarities is easy to apply to politics, too: (\#23) "What's the difference between politics and a poker player? Answer: For the latter, deception is just a game" (see https://www.vitsit. biz/vitsit/politiikkavitsit). The Internet abounds in political jokes, and in my article I can only speak of jokes in question form as riddles.

\section{“HYMYLÄ": PUNISHING THE UNLUCKY RIDDLEE}

The riddle types I have been discussing have one thing in common. A riddle is conceived as a question to which an answer has to be found. The imagery of old riddles was drawn from the agrarian domain and its uniform culture. Because people all led similar lives, it could be assumed that the riddlers would all be familiar with the empirical world from which the tradition drew its images. People thought it comic and risible if someone could not answer a question made up of familiar elements. Yet, however familiar the imagery was, an unexpected angle as in a riddle could be a surprise. In Finland the unsuccessful riddlee - the person who could not answer the riddle - could be punished. $\mathrm{He}$ or she was sent to a place called Hymylä (variant names such as Himola and Hölmölä are found), which could translate as Smileland. It was a fictitious, topsy-turvy world. The oldest known account of the Hymylä game appeared in Christfrid Ganander's Aenigmata Fennica (1783), and many such Hymylä incidents were mentioned in Finnish folk poetry in the early decades of the nineteenth century. Other scattered accounts of this folk-like farce are found in the folklore archives, and at the time of the riddle collection in 1967 the Hymylä punishment was still recalled.

There were three main episodes in the drama:

1. The departure for Hymylä, consisting of a proper outfit for the traveller;

2. The visit to Hymylä, usually being sent outside for a while or to the next room. Then the traveller was taken back in;

3 . The account of the journey.

Before the game began, the participants had agreed on how many riddles could be answered incorrectly before a riddlee was sent off to Hymylä. Usually the number was three. As soon as someone had given three wrong answers, the Hymylä episode followed. There were two opposing protagonists in the drama: the incompetent riddlee and the group putting the sentence into practice. Symbolically the unlucky riddlee was excluded from the group. Departure for Hymylä might have taken place to the accompaniment of a jingle, as one informant writes: "If you didn't know [the answers], you got sent to Hymylä. They said, 'Hush, hush to Hymylä, for not knowing even that"' ("Hyys, hyys, Hymylään! 
kun et sitäkään tiedä”) (SKS KRA: Taimi Pitkämäki AK 14:1.1967). A prelude was sometimes added to the trip to Hymylä. Participants at the riddling session would find ridiculous garments for the traveller: "Thus the girl was soon ready for Hölmölä. Now she was dressed in the oddest, 'billygoat' fashion, and was sent out of the living room" (ibid.).

On the victim's return to the group it was often expected that an account of the visit should be presented, reporting on the reception and treatment afforded to the traveller at the destination. However, the opposite could take place, so that members of the group would pretend to be the people of Hymylä, who would talk about the luckless traveller and amuse the rest of the group. The record continues:

Then began the fantasising about how she would be received in Hölmölä. Someone tells that Hölmölä's dogs are barking, whereat the children go to see what they are barking at, and they bring back the news that a ragged old woman is coming who's drawn by a cat and the sleigh's upside-down. In addition, she has horns on her head. Hölmölä's housewife takes fright just as she is salting her butter, and in her fright she throws ashes instead of salt in her butter, then overturns the milk pail into the hearth and lights the fire with her church silk. The daughter of the house turns a slops bucket over the stranger's eyes. When the latter asks to be allowed to wash, she is given a tar bucket and ordered to dry herself with bedding straw. Then she is asked about news from the world. When she doesn't know what else to say apart from those unsolved riddles, the poor creature, the likes of her, is pitied and given chaff mixed with buttermilk, the heads of last year's herrings and the holes of ring bread for her food. (Virtanen 1977: 81)

The humour in the description springs from the fact that the familiar farm milieu is turned upside-down and the unlucky riddlee is showered with scorn and disgusting or fanciful things to eat or to wash with. One amusing detail is the question about the world news, and it speaks of a time when news was predominantly oral and local. Obviously Hymylä is a topsy-turvy world in which all the customs and practices of our world are reversed or wrongly executed.

The description of Hymylä was comic because it was so exaggerated and its purpose was to amuse those who had managed to give the right answers. Hymylä represented popular ridicule in its most typical form. The grotesque jesting gave rise to hilarity in the group of players. At the same time people might stress that "we did our best to remember, to make sure we didn't get sent to Himola, because that was a disgrace", or "people were loath to join in the riddling for fear of being disgraced" (Kaivola-Bregenhøj 2001). Although it was only a game, the trip to Hymylä could cause anxiety. "The trip to Hymylä was so frightening that it was liable, even later at night, to disturb sleep if one 
had received that rebuking in the evening" (SKS KRA: HAKS 769.1927). The reverse of humour and comedy was constantly present, because anyone could, at any moment, be made to look stupid.

The role-exchange as such is not a device of the Finnish Hymylä game alone, for it is known internationally as a form of popular jesting in, for example, Estonian and Scandinavian poetry (Kaivola-Bregenhøj 2001: 114-116). In Estonia there are - contrary to the tradition in Finland - real geographical places "where riddlees were sent after the answer - for example Rasina and Üikkala and Uikala" (Voolaid 2011: 28).

Hymylä was an extension of true riddles, now mostly forgotten. Today's joking questions do not require a performing situation. They are slipped into the general discourse and may be posed either as a series or individually. The aim of these kinds of riddle jokes is to surprise and trick the riddlee and force him or her to admit they cannot find the answer. No wonder, since it is impossible for a novice to guess the answer. Once the guesser has become more familiar with the genre, the semantic construction may open up to the riddlee. Riddle jokes may incorporate the idea put forward by Alan Dundes, who has said that one of folklore's "most important functions is permitting action that is usually not approved" (Dundes 1965: 277). In decent language there are words that should not be used, but if hidden in a joking question, their vulgarity has a comic element.

\section{RIDDLE HUMOUR}

Why were riddles posed, and what did they give to the community? Both true riddles and joking questions were a way of learning social mores: in addition to having fun and a good laugh together, people had to learn to tolerate being misled or bluffed without getting offended. There were several different functions simultaneously at work in a riddling situation, only some of which are perhaps immediately evident. Riddling provides a form of entertainment, but at the same time the communication fosters a sense of affinity among those taking part, brings cultural metaphors and terminology, and expresses the values and norms of the community. The laughter surrounding riddles was of many kinds, from questioning to relief and from amusement to jeering. Not only could laughter spring from humour but also from the gathering and the conviviality that it brought about. Taking turns has always been an important part of riddling, because it ensures that the game continues. People's sense of humour differed, but riddling gave it collective limits and demonstrated what was permissible and what was not. 
Riddles open a window on the ambiguity of language and tradition. The humour in riddles is a special mixture of creative or innovative word play, making the familiar seem unfamiliar, pulling the rug from under the riddlee's feet by violating the norm, wielding power, and discovering comic elements even in places where no one thought to look for them.

\section{NOTES}

1 Finnish is pronounced more or less as it is written. Some speakers have difficulty with voiced plosives, such as [d] and [g], because these do not occur in spoken Finnish.

\section{ARCHIVAL SOURCES}

$\mathrm{AK}=$ Arvoituskilpakeruu (Collecting riddles by the SKS through tradition competitions). The Folklore Archives, Finnish Literature Society, 1967.

HAKS = Hämeenlinnan alakouluseminaari (Collections of the Hämeenlinna Junior School Seminary).

SKS KRA = Suomalaisen Kirjallisuuden Seura, Kansanrunousarkisto (Collections of the Folklore Archives of the Finnish Literature Society).

Ulla Lipponen = Ulla Lipposen keräelmät 5811-5812. 1987 (archival materials collected by Ulla Lipponen).

\section{REFERENCES}

Akínyẹmí, Akíntúndé 2015. Orature and Yorùbá Riddles. New York: Palgrave Macmillan. DOI: $10.1057 / 9781137502636$.

Anttonen, Pertti J. 2000. Riddle Jokes in the Negotiation of a Love Relationship. In: Maria Vasenkari \& Pasi Enges \& Anna-Leena Siikala (eds.) Telling, Remembering, Interpreting, Guessing: A Festschrift for prof. Annikki Kaivola-Bregenhøj on her 60th birthday, 1st February 1999. Joensuu: Suomen Kansantietouden Tutkijain Seura, pp. 246-256.

Barley, Nigel F. 1974. Structural Aspects of the Anglo-Saxon Riddle. Semiotica, Vol. 10, No. 2, pp. 143-176. http://dx.doi.org/10.1515/semi.1974.10.2.143.

Bregenhøj, Carsten 1988. Skolbarns humor. [Schoolchildren's Humor.] In: Carsten Bregenhøj \& Marie Johnson (eds.) Blodet droppar, blodet droppar! Skolbarns humor. [Blood Is Dripping, Blood Is Dripping! Schoolchildren's Humor.] Helsingfors: Schildts, pp. 171-210.

Brunvand, Jan Harold 1970. Some Thoughts on the Ethnic-Regional Riddle Jokes. Indiana Folklore, Vol. 3, No. 1, pp. 128-142. Available at https://babel.hathitrust.org/cgi/ pt?id=mdp.39015032118294;view=1up;seq=413, last accessed on July 18, 2017. 
Davies, Christie 1990. Ethnic Humor Around the World: A Comparative Analysis. Bloomington: Indiana University Press.

Davies, Christie 1998. Jokes and Their Relation to Society. Berlin: Mouton de Gruyter. Dundes, Alan 1965. The Study of Folklore. London: Prentice Hall.

Dundes, Alan 1971. A Study of Ethnic Slurs: The Jew and the Polack in the United States. The Journal of American Folklore, Vol. 84, No. 332, pp. 186-203. http:// dx.doi.org/10.2307/538989.

Dundes Alan \& Hauschild, Thomas 1983. Auschwitz Jokes. Western Folklore, Vol. 42, No. 4, pp. 249-260. http://dx.doi.org/10.2307/1499500.

Ganander, Christfrid 1970 [1783]. Aenigmata Fennica: Suomalaiset arvotuxet, Wastausten kansa. [Finnish Riddles with Answers.] Helsinki: Suomalaisen Kirjallisuuden Seura.

Haring, Lee 1985. Malagasy Riddling. Journal of American Folklore, Vol. 98, No. 388, pp.163-190. DOI: 10.2307/540438.

Kaivola-Bregenhøj, Annikki 1974. Perinteellinen ja muuttuva arvoitus. [Traditional and Changing Riddles.] In: Hannu Launonen \& Kirsti Mäkinen (eds.) Folklore tänään. Helsinki: Suomalaisen Kirjallisuuden Seura, pp. 107-126.

Kaivola-Bregenhøj, Annikki 2001. Riddles: Perspectives on the Use, Function and Change in a Folklore Genre. Helsinki: Finnish Literature Society.

Klintberg, Bengt af 1978. Varför har elefanten röda ögön? Om absurda skämtgåtor bland skolbarn. [Why Does the Elephant Have Red Eyes? About Absurd Jokes among Schoolchildren.] In: Bengt af Klintberg. Harens klagan och andra uppsatser om folklig diktning. [The Wailing Rabbit and Other Essays on Folk Poetry.] Stockholm: PAN / Norstedt, pp. 73-95.

Launonen, Hannu 1966. Varas menee aittaan... [The Thief Goes to the Shed...] Suomalainen Suomi, Vol. 6, pp. 374-379.

Morreall, John 1989. Enjoying Incongruity. Humor: International Journal of Humor Research, Vol. 2, No. 1, pp. 1-18. http://dx.doi.org/10.1515/humr.1989.2.1.1.

Noyes, Dorothy 1997. Riddle Joke. In: Thomas A. Green (ed.) Folklore: An Encyclopedia of Beliefs, Customs, Tales, Music, and Art, Vol. 2. Santa Barbara, CA: ABC-CLIO, pp. 730-732.

Pepicello, W. J. 1989. Ambiguity in Verbal and Visual Riddles. Humor: International Journal of Humor Research, Vol. 2, No. 3, pp. 207-215. http://dx.doi.org/10.1515/ humr.1989.2.3.207.

Preston, Michael J. 1982. The English Literal Rebus and the Graphic Riddle Tradition. Western Folklore, Vol. 41, No. 2, pp. 104-138. http://dx.doi.org/10.2307/1499785.

Price, Roger 1953. Droodles. Los Angeles: Simon \& Schuster.

Raskin, Victor 1985. Semantic Mechanism of Humor. Dordrecht: D. Reidel.

Roemer, Danielle M. 1982. In the Eye of the Beholder: A Semiotic Analysis of the Visual Descriptive Riddle. The Journal of American Folklore, Vol. 95, No. 376, pp. 173-199. http://dx.doi.org/10.2307/540717.

Virtanen, Leea 1960. Arvoitus ja sen tehtävä. [Riddles and Their Functions.] In: Jouko Hautala (ed.) Jumin keko: tutkielmia kansanrunoustieteen alalta. [Studies in the Field of Folklore Research.] Helsinki: Suomalaisen Kirjallisuuden Seura, pp. 144-189. 
Virtanen, Leea 1977. On the Function of Riddles. In: Leea Virtanen \& Annikki KaivolaBregenhøj \& Aarre Nyman (eds.) Arvoitukset / Finnish Riddles. Helsinki: Suomalaisen Kirjallisuuden Seura, pp. 77-89.

Virtanen, Leea \& Kaivola-Bregenhøj, Annikki \& Nyman, Aarre (eds.) 1977. Arvoitukset / Finnish Riddles. Suomalaisen Kirjallisuuden Seuran Toimituksia 330. Helsinki: Finnish Literature Society.

Voolaid, Piret 2009. Narrative Droodles as Humorous Miniature Fairy Tales? Acta Ethnographica Hungarica, Vol. 54, No. 1, pp. 143-154. https://doi.org/10.1556/ AEthn.54.2009.1.13.

Voolaid, Piret 2010. Humorous Interpretations of Abbreviations as a Socio-Cultural Phenomenon. Folklore: Electronic Journal of Folklore, Vol. 46, pp. 61-82. http:// dx.doi.org/10.7592/FEJF2010.46.voolaid.

Voolaid, Piret 2011. Eesti mõistatused kui pärimusliik muutuvas kultuurikontekstis. [Estonian Riddles as a Folklore Genre in a Changing Cultural Context.] Dissertationes folklorsticae Universitatis Tartuensis 16. Tartu: Tartu Ülikooli Kirjastus. Available at http://dspace.ut.ee/handle/10062/17528?show=full\&loca le-attribute=en, last accessed on July 18, 2017.

Wessman, V[ilhelm] E[liel] V[iktorinus] (ed.) 1949. Finlands svenska folkdiktning IV: Gåtor. Skrifter utg. av Svenska Litteratursällskapet $i$ Finland 327. [Finnish Swedish Folklore IV: Riddles. Writings Published by the Swedish Literature Society in Finland.] Helsingfors: n.p. 